\title{
G-Protein Coupled Receptor 183
}

National Cancer Institute

\section{Source}

National Cancer Institute. G-Protein Coupled Receptor 183. NCI Thesaurus. Code C101354.

G-protein coupled receptor 183 (361 aa, $\sim 41 \mathrm{kDa}$ ) is encoded by the human GPR183 gene. This protein is involved in both B-cell maturation and localization. 